\title{
THE LAND OF HAȚEG. STUDY OF REGIONAL GEOGRAPHY
}

\section{Andrei NIȚOAIA}

Babeș-Bolyai University, Cluj-Napoca, Faculty of Geography, ROMANIA

nitoaia.andrei@gmail.com

Jara Haţegului. Studiu de Geografie Regională [The Land of Hațeg. Study of Regional Geography] / Gheorghe-Gavrilă HOGNOGI; Presa Universitară Clujeană, 2016; 270 p.

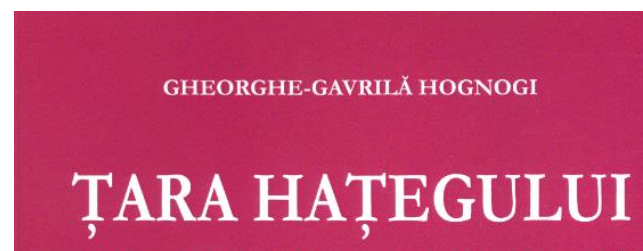

\section{STUDIU DE GEOGRAFIE REGIONALĂ}

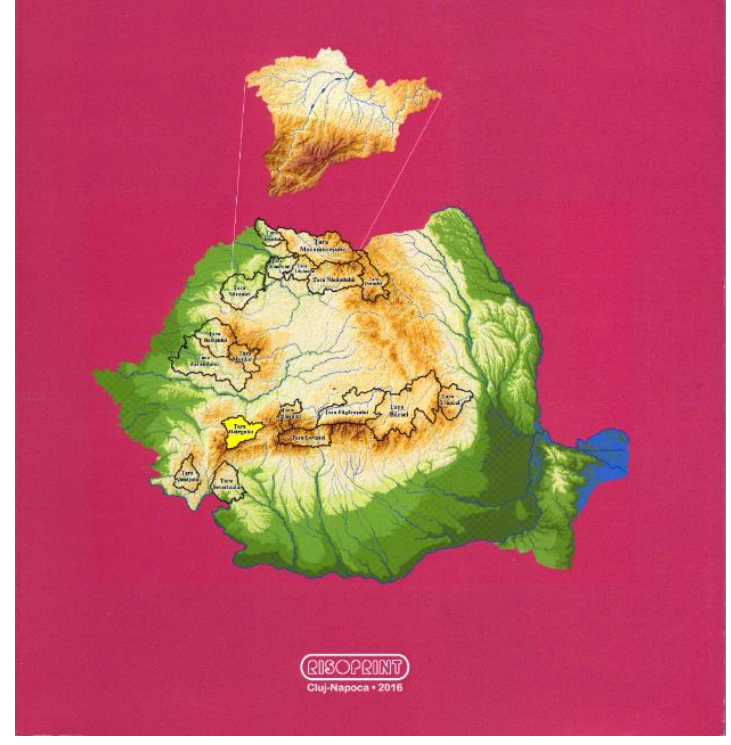

This book is the objective and new successful result of the author's efforts to bring to the readers' attention the complexity of the "land" type territorial systems, exemplifying through the Land of Hațeg.

In the six chapters of his book, Gheorghe-Gavrilă Hognogi succeeds in answering to the two questions which are also the hypotheses of his research, namely: (a) "To what extent and through which means the territorial system of the Land of Hațeg is viable and functional today?" (p. 26) and (b) "Whether and how can a study of Regional Geography become a tool for the stakeholders in charge with territorial planning and arrangement?" (p. 26).

The first two chapters (pp. 25-66) focus on theoretical and methodological issues, as well as on the role of the historical evolution in the appearance of this "land". Due to the numerous historical documents that the author used during research, he was able to underline the historical importance of the analysed region. At the same time, related to the historical issues, the author paid special attention to the built heritage, in general, and to the archaeological heritage in particular, as "[...] here there are representative archaeological sites for the Romanian people (Colonia Ulpia Traiana Augusta Dacica Sarmizegetusa, the Royal Fortress of Hațeg, the ruins of the Roman bridge)" (p. 211).

In Chapter 3, "Description of the Natural Environment and Functional Interdependencies of the Land of Hațeg" (pp. 67-128), due to the original graphical material and to the information obtained during field work (e.g. photos, old maps, discussions with the locals, etc.), the author represents in an original manner the natural features of the Land of Hațeg, all the geographical elements like relief (altitudes, slope, slope orientation), geology, hydrology, climate, soil, etc., being approached in the above-mentioned chapter. 
Being a complex, integrated approach, in Chapters 4 and 5 (pp. 129-178; pp. 178-226) the book presents the characteristic features the population and settlements in the Land of Hateg, and the economic ones respectively. A result of the author's efforts to identify the dysfunctions of each researched topic mentioned above is a series of solutions that he proposes. These solutions represent a significant source of information for both (a) the stakeholders in charge of territorial planning and of implementing territorial development strategies and (b) future research in Regional Geography.

The last chapter, "The Functionality of the Land of Hațeg Territorial System" (pp. 227-235), although shorter, is very important because it reveals the functionality of this "land" type territorial system, the research results and the validity of the hypotheses (p. 26).

Although reading this book may sometimes be tiresome because of its information rich contents and because of author's using enumerations, certain details could be highly useful for stakeholders in the field of territorial planning and development and also for researchers interested in the Land of Hațeg, and, in addition, for those interested in the history of this "land" and its significance for Romania. Moreover, the cartography presented in this book is exceptional due to the author's professional use of GIS.

To sum up, the book authored by Gheorghe-Gavrilă Hognogi, Ph.D., "The Land of Hațeg. Study of Regional Geography", due to its originality and results, is a model for young researchers and it stands as proof for hard work. The Land of Hațeg is a viable territorial system, with huge potential and which, through appropriate management and integrated approach of natural, human, cultural and economic resources, may undergo sustainable development and prove that "land" type units stand as development models and offer solutions for diverse present societal problems. 